\title{
Prevalence of Polymicrobial Infection in Urethritis
}

\section{Üretritte Polimikrobial Enfeksiyon Prevelansı}

\author{
(1) Mehmet Sarıer 1,2 \\ ${ }^{1}$ Medical Park Hospital, Clinic of Urology, Antalya, Turkiye \\ 2 istinye University Faculty of Medicine, Department of Urology, Istanbul, Turkiye
}

\section{What's known on the subject? and What does the study add?}

Today, the prevalence of polymicrobial infection in acute urethritis is remarkable. It seems that this infection will be more commonly encountered in clinical practice with increasing use of polymerase chain reaction assay for the diagnosis. Empirical antibiotics administration should be avoided for the treatment and the principle for treatment of the pathogen should be adopted.

\begin{abstract}
Objective: Urethritis is the most common sexually-transmitted disease in men and is classified as gonococcal (GU) and non-gonococcal (NGU) according to the pathogens. Increased urethritis prevalence in recent years has brought the presence of polymicrobial infection into question. The objective of this study was to investigate the prevalence of polymicrobial infections in patients diagnosed with urethritis in a urology outpatient clinic, based on real-time multiplex polymerase chain reaction (Rt-MPCR) assay outcomes.

Materials and Methods: Data of 171 patients diagnosed with urethritis and undergone Rt-MPCR analysis in a urology outpatient clinic between February 2017 and June 2018 were retrospectively studied. The pathogens that could be detected by the Rt-MPCR were Chlamydia trachomatis, Neisseria gonorrhoeae, Mycoplasma hominis, Mycoplasma genitalium, Ureaplasma urealyticum, Ueroplasma parvum, Gardnerella vaginalis, Trichomonas vaginalis, Candida albicans and herpes simplex virus type 1-2.

Results: The mean age of 171 patients was 33.8 (19-56) years. According to the Rt-MPCR outcomes, polymicrobial infections were found in 16.9\% (29/171) of patients. Two-pathogen polymicrobial urethritis was found in 14\% (24/171) of the patients, and three-pathogen polymicrobial urethritis in 2.9\% (5/171). Among the cases of polymicrobial urethritis, coexistence of both GU and NGU pathogens was found in 17.3\% (5/29) and that of only NGU pathogens in $82.7 \%$ (24/29). Overall distribution of urethritis pathogens was found to be as follows: Chlamydia trachomatis 22.9\%, Neisseria gonorrhoeae $21.7 \%$, Gardnerella vaginalis 16.8\%, Ureaplasma urealyticum 14.2\%, Mycoplasma genitalium 10.5\%, Ueroplasma parvum 4.7\%, Mycoplasma hominis 3.7\%, Trichomonas vaginalis 3.1\%, Candida albicans 1.8\% and herpes simplex virus type $-21.2 \%$.

Conclusion: The presence of polymicrobial urethritis should be taken into consideration when planning treatment for urethritis. Particularly, the association of NGU urethritis pathogens should be considered in the cases of polymicrobial urethritis.
\end{abstract}

Keywords: Urethritis, Non-gonogoccal urethritis, PCR, Polymicrobial urethritis

\section{Öz}

Amaç: Üretrit erkeklerde en sık görülen cinsel yolla bulaşan hastalıktır ve patojenlerine göre gonokoksik (GU) ve non-gonokoksik üretrit (NGU) olarak sınıflandırımaktadır. Son yıllarda artan üretrit olguları polimikrobial enfeksiyon varlığını da gündeme getirmiştir. Bu çalışmanın amacı üroloji polikliniğinde üretrit tanısı alan hastalarda gerçek zamanlı multiplex polimeraz zincir reaksiyonu (Rt-MPCR) sonuçlarına göre polimikrobial enfeksiyon prevelansının araştırılmasıdır.

Gereç ve Yöntem: 2017 Şubat - 2018 Haziran arasında üroloji polikliniğinde üretrit tanısı alan ve Rt-MPCR analizi yapılan 171 hastanın dataları retrospektif incelendi. Rt-MPCR kiti tarafından saptanabilen patojenler Chlamydia trachomatis, Neisseria gonorrhoeae, Mycoplasma hominis, Mycoplasma genitalium, Ureaplasma urealyticum, Ueroplasma parvum, Gardnerella vaginalis, Trichomonas vaginalis, Candida albicans ve herpes simpleks virüsü tip 1-2 idi.

Correspondence: Mehmet Sarier MD, Medical Park Hospital, Clinic of Urology, Antalya; İstinye University Faculty of Medicine, Department of Urology, Turkiye E-mail: drsarier@gmail.com ORCID-ID: orcid.org/0000-0002-8656-7416

Received: 08.11.2018 Accepted: 12.01.2019

Cite this article as: Sarıer M. Prevalence of Polymicrobial Infection in Urethritis. J Urol Surg 2019;6(3):180-183.

${ }^{\circ}$ Copyright 2019 by the Association of Urological Surgery / Journal of Urological Surgery published by Galenos Publishing House. 
Bulgular: Çalışmaya alınan 171 hastanın ortalama yaşı 33,8 (19-56) idi. RT-MPCR sonucuna göre \%16,9 (29/171) hastada polimikrobial enfeksiyon mevcuttu. Yüz yetmiş bir hastanın 24'ünde $(\% 14) 2$ patojenli, 5 'inde $(\% 2,9)$ ise 3 patojenli polimikrobial üretrit mevcuttu. Polimikrobial üretritli 29 olgu içinde NGÜ patojenlerinin birlikteliği 24'ünde $(\% 82,7)$ bulunurken, GU ve NGU patojenlerinin birlikteliği 5'inde (\%17,3) bulundu. Üretrit patojenlerinin genel dağılımı ise Chlamydia trachomatis \%22,9, Neisseria gonorrhoeae \%21,7, Gardnerella vaginalis \%16,8, Ureaplasma urealyticum $\% 14,2$, Mycoplasma genitalium \%10,5, Ueroplasma parvum \%4,7, Mycoplasma hominis \%3,7, Trichomonas vaginalis \%3,1, Candida albicans \% 1,8 ve herpes simpleks virüsü tip-2 \%1,2 idi.

Sonuç: Üretrit tedavisini planlanırken polimikrobial enfeksiyon varlığı göz önünde bulundurulması gerekmektedir. Polimikrobial üretrit içerisinde ise özellikle NGU üretrit patojenlerinin birlikteliği düşünülmelidir.

Anahtar Kelimeler: Üretrit, Non-gonokoksik üretrit, PCR, Polimicrobial üretrit

\section{Introduction}

Urethritis in men is a clinical presentation developing often due to sexually-transmitted pathogens and is characterized by dysuria and urethral discharge (1). Urethritis is an important cause of morbidity in sexually active individuals and remains a major medical, social and economic burden worldwide. Classically, urethritis is classified as non-gonococcal (NGU) and gonococcal (GU) (2). In the world, approximately 62 million new cases of GU and 89 million new cases of NGU are reported each year, and these figures keep increasing (3). With annually increasing prevalence, wrong or incomplete treatment approaches have brought the presence of polymicrobial infection into question $(4,5)$. Urethritis is diagnosed upon the observation of $\geq 5$ polymorphonuclear leukocyte (PMNL/HPF) per high power field in gram staining of urethral smear and/or discharge sample (6). In the identification of urethritis pathogens, nucleic acid amplification tests, such as polymerase chain reaction (PCR) assay, are the diagnostic methods recommended by international guidelines for their ability to identify many pathogens in a single sample within a short amount of time with high sensitivity and specificity $(7,8)$. There is no sufficient data on the prevalence of polymicrobial urethritis in our country. The objective of this study was to investigate the prevalence of polymicrobial infections in patients diagnosed with urethritis in our outpatient clinic, based on real-time multiplex PCR (RtMPCR) assay outcomes.

\section{Materials and Methods}

Upon receiving ethics committee approval from Antalya Medical Park Hospital Facility (approval no: 011/2018), RtMPCR analysis results of 171 patients, who had presented to our outpatient clinic with the complaints of urethral discharge, dysuria and pruritus in the urethra, and had $\geq 5$ PMNL/HPF in the gram staining of urethral discharge/smear sample or had positive leukocyte esterase assay (Combur-Test ${ }^{\circledR}$-Roche) for their first urine sample, were collected. This retrospective study was performed in accordance with the principles of the
Declaration of Helsinki. Pathogens in the urethral discharge/ smear samples obtained from the patients were investigated with Rt-MPCR assay. PREP-NA PLUS and PREP-GS PLUS extraction kits manufactured by DNA-Technology ${ }^{\circledR}$ (Moscow, Russia) were used. Results were analyzed by using Elite Prime Real ${ }^{\circledR}$ Time PCR of the same company. Absolute presence of Neisseria gonorrhoeae, Chlamydia trachomatis, Mycoplasma genitalium, Trichomonas vaginalis and herpes simplex virus type 1-2 were considered to be positive. For opportunistic pathogens of Ureoplasma urealyticum, Ureoplasma parvum, Gardnerella vaginalis, Candida albicans and Mycoplasma hominis, $>10^{4}$ microbial load was considered positive as per the recommendations of the manufacturer.

\section{Statistical Analysis}

All statistical analyses were performed using the SPSS statistical software (SPSS for Windows version 16.0 SPSS Inc. Chicago IL, USA).

\section{Results}

The mean age of the 171 patients was 33.8 (19-56) years. At least one pathogen was detected in 124 (72.6\%) patients. According to Rt-MPCR results, polymicrobial infections were found in 16.9\% (29/171) of patients. There was two-pathogen polymicrobial urethritis in 14\% (24/171), and three-pathogen polymicrobial urethritis in 2.9\% (5/171) of the patients. Among the cases of polymicrobial urethritis, coexistence of both $\mathrm{GU}$ and NGU pathogens was found in 17.3\% (5/29) and coexistence of only NGU pathogens was found in $82.7 \%$ (24/29) of the patients. Overall distribution of urethritis pathogens was as follows: Chlamydia trachomatis 22.9\%, Neisseria gonorrohoea 21.7\%, Gardnerella vaginalis 16.8\%, Ureoplasma urealyticum 14.2\%, Mycoplasma genitalium 10.5\%, Ureoplasma parvum 4.7\%, Mycoplasma hominis 3.7\%, Trichomanas vaginalis 3.1\%, Candia albicans $1.8 \%$, and herpes simplex virus type-2 $1.2 \%$ (Figure 1). No pathogens were detected with Rt-MPCR in 47 $(27.4 \%)$ patients. 


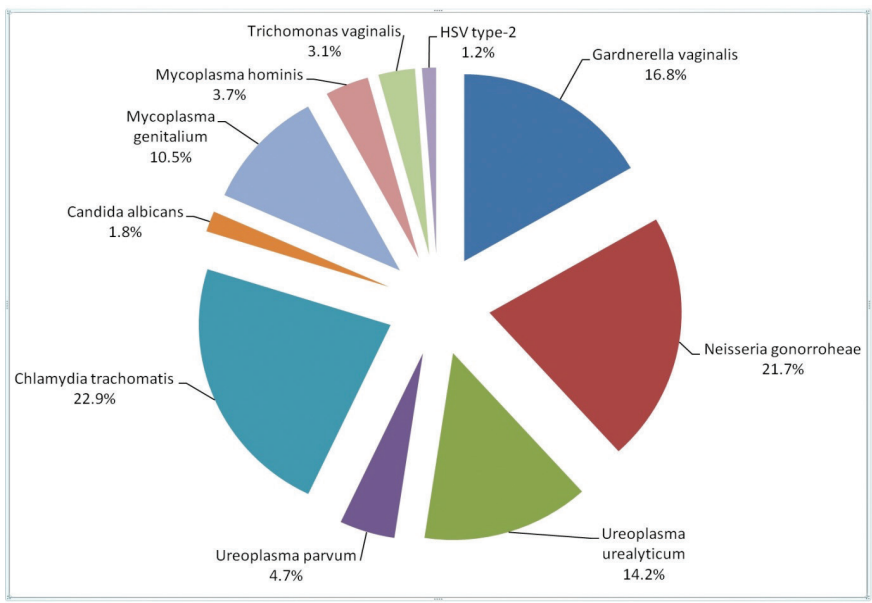

Figure 1. Distribution of urethritis pathogens

\section{Discussion}

Urethritis affects the society as an economic and social burden. In the United States, approximately 4 million urethritis cases are being reported every year (7). Unfortunately, there is no sufficient data on this subject in our country. With the widespread use of nucleic acid amplification assays, the number of reported cases of NGU increased at a higher rate compared with GU cases in recent years. As a result, the role of gram staining in the identification of NGU has become questionable. In the classical evaluation, NGU diagnosis is made when intracellular diplococci are not seen on microscopic evaluation of a urethral gram stained smear. Recent studies recommended lowering the diagnostic criteria of the diagnosis to $\geq 2$ PMNL/HPF due to false negative results obtained especially in NGU cases with mild inflammation $(9,10)$. In a recent study conducted by Sarier et al. (11), the authors showed that gram staining had 92.9\% sensitivity in GU diagnosis and only $55.6 \%$ sensitivity in NGU when the threshold was $\geq 5 \mathrm{PMNL} / \mathrm{HPF}$, while sensitivity in GU diagnosis increased to $100 \%$ and to $92.6 \%$ in NGU diagnosis when the cutoff value was lowered to $\geq 2$ PMNL/HPF. Therefore, it must be noted that NGU cases can be missed in clinics where nucleic acid amplification assays such as PCR are not performed. It is also clear that these cases can cause serious economic and social burden due to their infectiousness. This will also lead to increased prevalence of polymicrobial urethritis.

The place of opportunistic pathogens in NGU and sexually transmissibility of NGU are also controversial (12). However, there are publications in the literature suggesting that Mycoplasma hominis, Gardnerella vaginalis, Candida albicans, and Ureaplasma species, which can be exist as normal commensal flora, cause urethritis at high microbial loads $(2,13,14)$. Among these pathogens, only Ureoplasma ureolyticum is specified in the guidelines as a cause of urethritis (8). In such case, Rt-MPCR devices that can perform quantitative measurement of microbial load are very beneficial for preventing false positive results. In a urethritis prevalence study, we conducted in 2016, evaluation using a PCR device without quantitative measurement of microbial load revealed a Ureoplasma ureolyticum prevalence of 27.1\% (15), while evaluation using PCR with quantitative measurement showed a Ureoplasma ureolyticum prevalence rate of $14.2 \%$ only. Therefore, we believe that calculation of microbial load in the evaluation of opportunistic pathogens is necessary to avoid false positive diagnoses. Urethritis pathogens mostly develop in association with sexually-transmitted pathogens. However, even if urethritis occurs after sexual intercourse, not only sexually-transmitted pathogens but all of the abovementioned opportunistic pathogens should be taken into consideration as potential factors for both singular and polymicrobial urethritis. It can be considered that the pathogen develops in relation with the disruption of the existing flora, instead of transmission. However, further comparative largescale studies are warranted. In our study, coexistence of NGU pathogens was observed in $82.7 \%$ of polymicrobial urethritis cases. Among all the urethritis pathogens, the rate of approximately 27\% for Mycoplasma hominis, Ureoplasma parvum, Gardnerella vaginalis and Candida albicans, which have opportunistic characteristics, is of particular interest.

Literature review for polymicrobial urethritis showed that majority of the studies are about the coexistence of both GU and NGU pathogens $(16,17)$. However, coexistence of GU-NGU pathogens was detected only in $17.3 \%$ our patients. The reason may be due to the fact that, especially with the increasing use of PCR technology, we detect more NGU pathogens which are difficult to identify with conventional methods.

As conventional methods like culture assays require long time (3-7 days) to identify urethritis pathogens, it is recommended to initiate empiric treatments in an attempt to prevent the patient from infecting other individuals through sexual intercourse during the test period. Urethritis pathogens are very diverse and sometimes can include more than one-species. Therefore, the effectiveness and sufficiency of empiric treatments became questionable. In our study, the prevalence rate of $16.9 \%$ for polymicrobial urethritis also suggests this situation. Increasing burden and costs of urethritis treatment led to the necessity of fast and reliable laboratory techniques for the identification of related pathogens. PCR analysis can provide results with 96\% sensitivity and 100\% specificity in less than 24 hours (18) enabling timely initiation of treatment without any delay. This will lead to an easier infection control. Therefore, recent international guidelines recommend termination of empiric treatment, and using cause-specific treatment after bacterial identification $(7,8)$.

It has been reported that responsible pathogens cannot be identified in 20-30\% of men with urethritis (19). In our study, the 
rate of the group that can be identified as idiopathic urethritis, for which no agents were determined, was found to be $27.4 \%$. Idiopathic urethritis may not have an infectious etiology, or this condition may be caused by unidentified infectious agents circulating in the sub-groups of the population, different than in ones infected by conventional urethritis pathogens.

This study has some limitations. It was not specified whether the patients included in the study had received prior medical treatment. Therefore, it could not be shown whether the polymicrobial urethritis cases were primary infections or concomitant infections caused by an existing pathogen.

\section{Conclusion}

The presence of polymicrobial urethritis should be taken into consideration when planning treatment for urethritis. Particularly coexistence of NGU urethritis pathogens should be considered in the cases of polymicrobial urethritis. RtMPCR analysis is a highly effective method for the detection of microbial infection in urethritis. Therefore, clinicians should avoid empiric treatment approaches and prefer pathogenoriented treatment approaches.

\section{Ethics}

Ethics Committee Approval: The study were approved by Medical Park Hospital Local Ethics Committee (protocol number: 011/2018).

Informed Consent: Informed consent was obtained from all individual participants included in the study.

Peer-review: Externally peer-reviewed.

Financial Disclosure: The author declared that this study received no financial support.

\section{References}

1. Gaydos C, Maldeis NE, Hardick A, Hardick J, Quinn TC. Mycoplasma genitalium compared to chlamydia, gonorrhoea and trichomonas as an aetiological agent of urethritis in men attending STD clinics. Sex Transm Infect 2009;85:438-440.

2. Ito $S$, Hanaoka $N$, Shimuta $K$, Tsuchiya $T$, Yasuda M, Yokoi $S$, Nakano $M$, Ohnishi $M$, Deguchi T. Male non-gonococcal urethritis: From microbiological etiologies to demographic and clinical features. Int J Urol 2016;23:325-331.

3. Mckechnie ML, Hillman R, Couldwell D, Kong F, Freedman E, Wang H, Gilbert GL. Simultaneous Identification of 14 Genital Microorganisms in Urine by
Use of a Multiplex PCR-Based Reverse Line Blot Assay. J Clin Microbiol 2009;47:1871-1877.

4. Khan A, Fortenberry JD, Juliar BE, Tu W, Orr DP, Batteiger BE. The prevalence of chlamydia, gonorrhea, and trichomonas in sexual partnerships: implications for partner notification and treatment. Sex Transm Dis 2005:32:260-264.

5. Stellrecht KA, Woron AM, Mishrik NG, Venezia RA. Comparison of multiplex PCR assay with culture for detection of genital mycoplasmas. J Clin Microbiol 2004;42:1528-1533.

6. Moi H, Hartgill U, Skullerud KH, Reponen EJ, Syvertsen L, Moghaddam A. Microscopy of Stained Urethral Smear in Male Urethritis; Which Cutoff Should be Used? Sex Transm Dis 2017;44:189-194.

7. Workowski KA, Bolan GA; Centers for Disease Control and Prevention. Sexually transmitted diseases treatment guidelines, 2015. MMWR Recomm Rep 2015;64:1-137.

8. Pickard $R$, Bartoletti $R$, Bjerklund-Johansen $T E$, Bonkat $G$, Bruyère $F$, Çek $M$, Grabe M, Tenke P, Wagenlehner F, Wullt B. EAU Guidelines on Urological Infections. Eur Assoc Urol 2016.

9. Orellana MA, Gómez-Lus ML, Lora D. Sensitivity of Gram stain in the diagnosis of urethritis in men. Sex Transm Infect 2012;88:284-287.

10. Rietmeijer CA, Mettenbrink CJ. Recalibrating the Gram stain diagnosis of male urethritis in the era of nucleic acid amplification testing. Sex Transm Dis 2012;39:18-20.

11. Sarier M, Sepin N, Duman I, Demir M, Hizel A, Göktaş \$̧, Emek M, Kukul E, Soylu A. Microscopy of Gram-stained urethral smear in the diagnosis of urethritis: Which threshold value should be selected? Andrologia 2018;50:e13143

12. Deguchi T, Yoshida T, Miyazawa T, Yasuda M, Tamaki M, Ishiko H, Maeda S. Association of Ureaplasma urealyticum (biovar 2) with nongonococcal urethritis. Sex Transm Dis 2004;31:192-195.

13. Manhart LE, Khosropour CM, Liu C, Gillespie CW, Depner K, Fiedler T, Marrazzo JM, Fredricks DN. Bacterial Vaginosis-Associated Bacteria in Men. Sex Transm Dis 2013;40:944-949.

14. Li J, Fan SR, Liu XP, Li DM, Nie ZH, Li F, Lin H, Huang WM, Zong LL, Jin JG, Lei H, Bai FY. Biased Genotype Distributions of Candida albicans Strains Associated with Vulvovaginal Candidosis and Candidal Balanoposthitis in China. Clin Infect Dis 2008;47:1119-1125.

15. Sarier M, Duman I, Göktaş Ş, Demir M, Kukul E. Results of Multiplex Polymerase Chain Reaction Assay to Identify Urethritis Pathogens. J Urol Surg 2017;4:18-22.

16. Bala M, Mullick JB, Muralidhar S, Kumar J, Ramesh V. Gonorrhoea \& its coinfection with other ulcerative, non-ulcerative sexually transmitted \& HIV infection in a Regional STD Centre. Indian J Med Res 2011;133:346-349.

17. Gottesman T, Yossepowitch O, Samra Z, Rosenberg S, Dan M. Prevalence of Mycoplasma genitalium in men with urethritis and in high risk asymptomatic males in Tel Aviv: a prospective study. Int J STD AIDS 2017;28:127-132.

18. Horii T, Ohtsuka H, Osaki M, Ohkuni H. Use of a dual priming oligonucleotide system to detect multiple sexually transmitted pathogens in clinical specimens. Lett Appl Microbiol 2009;49:46-52.

19. Bowie WR, Alexander ER, Stimson JB, Floyd JF, Holmes KK. Therapy for nongonococcal urethritis: double-blind randomized comparison of two doses and two durations of minocycline. Ann Intern Med 1981;95:306-311. 